\title{
THE IMPORTANCE OF LANDMARKS FOR THE PERCEPTION OF THE REgION'S ATTRACTIVENESS
}

\author{
Emil Drápela ${ }^{1}$; Tereza Brožková ${ }^{2}$ \\ Technical University of Liberec, \\ Faculty of Science, Humanities and Education, Department of Geography, \\ Studentská 1402/2, 46117 Liberec 1, Czech Republic

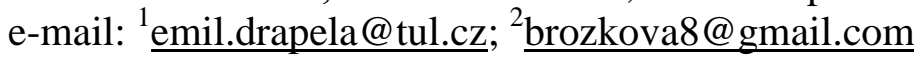

\begin{abstract}
There are a number of places in the Liberec Region that are very attractive to various forms of tourism. In our survey, we asked tourists who had visited this region what they liked most and what least, how they evaluated the facilities and the services and what they would recommend to their friends. During the evaluation, we realized that one of the most important factors influencing the overall perception of the tourist area was the process of creation of perceived space through its parts - landmarks. This article therefore tries to reflect on two geographic methods: the concept of place and method of mental mapping and on how the perceived space is generated from holiday experiences. Understanding this process may provide more effective forms of promotion of tourist areas in future.
\end{abstract}

\section{Keywords}

Liberec Region; Tourism; Landmark; Mental maps.

\section{Introduction}

This article is based on an application of subjectively perceived space theory, which helped us to understand how the relationship between the tourist and the place or a visited region is created. There are two theoretical concepts which describe this process: mental mapping (or mental maps), which was introduced by Kevin Lynch in 1960 [1], and Yi-Fu Tuan's concept of place $[2,3]$. Both of these concepts were further developed by other authors in the coming decades and formed the basis of new geographical paradigms. Leading Czech works in this field are a book by Tadeusz Siwek on the subject of mental maps [4] and Jaroslav Vávra's article [5] dealing with a place.

Lynch [1] describes how the geographical reality of the everyday life is perceived by individuals who have saved it in their minds as the cognitive image, which is then used during thinking. This cognitive image consists of paths, edges, districts, nodes and landmarks; these types of elements are collectively referred as Lynch elements. Paths are channels along which people move, e.g. streets, walkways or canals. Edges are barriers that separate one area from another, e.g. walls, railroad tracks or shorelines. Districts are areas with an identifiable character (physical and/or cultural) that people mentally "enter" and "leave", e.g. a business district or ethnic neighborhood. Nodes are strategic points and foci for travel, e.g. street corners, traffic junctions or city squares. Finally, landmarks are physical reference points, e.g. distinctive landforms, buildings and monuments.

From the perspective of the tourism three of Lynch elements, paths, districts and landmarks are important. A popular tourist path may be a road with views, hiking treks in the mountains, curvy country roads for bikers or recreational cycling trails. Districts perceived from the point-of-view of tourism are regions that are attractive for some reason, e.g. rock formations, 
forested mountains, river valleys or lake surroundings. Landmarks are differentiated from districts only by their size and meaning, which means that if it is a relatively homogeneous area where the elements are at a roughly same level of importance, it is the district, while if there is a central element with a higher importance that surpasses the rest, it is a landmark.

The important point is that the selection of these elements is based on remembering and cognition, implying that it is not a true image of reality, but the result of an experience. Hence, it may happen that from two elements of the same importance one becomes a landmark and the other does not. The difference is that in the first case, the individual created a relationship to the locality, which has become a place as understood by Tuan [3], whereas for the second location no such process has taken place. A key event in this process is the tourist's experience with the site.

\section{$1 \quad$ Research Objectives}

The aim of our research was to find out:

- what, in general, tourists liked during their stay in one of the predefined tourist areas and what they did not like,

- what kind of Lynch elements they mentioned in positive responses,

- what is the ratio of paths, districts and landmarks,

- how the creation of cognitive image of a tourist region affects its perceived attractiveness.

\section{$2 \quad$ Research Methods}

The main source of data for this article was a survey by Brožková [6] that had been carried out for the thesis. This questionnaire survey took place in the first half of 2015; the respondents were 111 people who in recent years had spent their holidays in the Liberec Region. For the purposes of this article, only one part of the questionnaire was used, namely the one with open questions asking visitors about their feelings about various tourist areas. At least one respondent from every region of the Czech Republic replied to the questionnaire, while most respondents were from Liberec, Central Bohemia and Hradec Králové regions. This corresponds to reality when most tourists in the Liberec Region come from those regions. The respondents answered only questions that concerned the tourist areas they had visited.

Most valuable natural areas in the Liberec Region are protected as a national park or protected landscape area. For this reason, we used the names of these areas in our questionnaire to term the main tourist regions. These regions do not cover the entire territory of the Liberec Region, but that was not the aim of the work. We defined the following tourist regions: the Giant Mountains, the Jizera Mountains, the Lusatian Mountains, the Central Bohemian Uplands, Kokoř́n Region and the Bohemian Paradise.

To determine how many tourists attend these tourist areas, it was necessary to define them at the municipal level. We used a simple criterion: if the municipality extends to the protected area, it is a part of the tourist region of the same name. As a result, we were able to obtain data about the number of visitors from the Czech Statistical Office, because these data are not publicly available for small villages. 
The main results of the questionnaire survey are shown in Tab. 1, which lists the most frequently mentioned pros and cons of staying in the selected tourist areas. The terms are sorted according to their frequency in the answers.

Tab. 1: Pros and cons of staying in the selected tourist areas of the Liberec Region

\begin{tabular}{|c|c|c|}
\hline Tourist area & Pros & Cons \\
\hline Giant Mountains & $\begin{array}{l}\text { Nature and landscape, views and } \\
\text { panoramas, tranquility and relaxation, } \\
\text { Sněžka, Labská louka, winter sports }\end{array}$ & $\begin{array}{l}\text { Too many tourists, bad behaviour of } \\
\text { other tourists, high prices, too many } \\
\text { asphalt trails, commercialization }\end{array}$ \\
\hline Jizera Mountains & $\begin{array}{l}\text { Nature and landscape, views and } \\
\text { panoramas, cross country skiing } \\
\text { trails, cycling and hiking trails, } \\
\text { Jizerka, Smrk, bogs, rocks }\end{array}$ & $\begin{array}{l}\text { Too many tourists, too many paved } \\
\text { trails, expensive and insufficient } \\
\text { parking, lack of restaurants, poor } \\
\text { accessibility by public transport }\end{array}$ \\
\hline $\begin{array}{l}\text { Lusatian } \\
\text { Mountains }\end{array}$ & $\begin{array}{l}\text { Nature and landscape, rocks, } \\
\text { mountains, tranquility, Luž, Zlatý } \\
\text { vrch, Lemberk, hiking trails, volcanic } \\
\text { hills }\end{array}$ & $\begin{array}{l}\text { Bad behaviour of other tourists, } \\
\text { insufficient promotion, poor } \\
\text { accessibility, missing bike trails, } \\
\text { waste along the roads }\end{array}$ \\
\hline $\begin{array}{l}\text { Bohemian } \\
\text { Central Uplands }\end{array}$ & $\begin{array}{l}\text { Nature and landscape, views, } \\
\text { observation towers, volcanic hills, } \\
\text { Milešovka, Panská skála, Boreč }\end{array}$ & $\begin{array}{l}\text { Worse transport accessibility, missing } \\
\text { ferries on the Elbe, chemical factory } \\
\text { in Lovosice, environmental pollution } \\
\text { in lowlands }\end{array}$ \\
\hline Kokořín Region & $\begin{array}{l}\text { Sandstone rock formations, castle } \\
\text { Kokořín, Kokořínský důl, Pokličky, } \\
\text { castle Houska }\end{array}$ & $\begin{array}{l}\text { Too many tourists, inadequate } \\
\text { availability of public transport, } \\
\text { commercialization, waste in forests }\end{array}$ \\
\hline $\begin{array}{l}\text { Bohemian } \\
\text { Paradise }\end{array}$ & $\begin{array}{l}\text { Sandstone rock formations, nature } \\
\text { and landscape, monuments, castles, } \\
\text { Trosky, Hrubá Skála, the Prachovské } \\
\text { Rocks, hiking trails, cycling trails }\end{array}$ & $\begin{array}{l}\text { Too many tourists, ticket prices, } \\
\text { parking prices, quality and quantity } \\
\text { of restaurants, commercialization }\end{array}$ \\
\hline
\end{tabular}

Source: Own compilation based on the survey [6]

Tab. 1 shows that the most frequent answers are general characteristics of the tourist areas, such as "nature and landscape", "views" and "rocks". Afterwards, the respondents generally characterize the qualities of the tourist area, in most cases they point out some selected locations they liked most. These sites can be considered as the Lynch elements. The most popular sites, which can be classified as landmarks, were: Sněžka and Labská louka in the Giant Mountains, Jizerka and Smrk in the Jizera Mountains, Luž, Zlatý vrch and Lemberk in the Lusatian Mountains, Milešovka, Panská skála and Boreč in the Bohemian Central Uplands, Kokořín Castle, Pokličky and Houska Castle in the Kokořín Region, and Trosky and Hrubá Skála in the Bohemian Paradise. The most popular sites, which can be classified as a district, were: the volcanic hills area in the Lusatian Mountains, the sandstone rock formations in the Kokořín Region and the Bohemian Paradise, Kokořínský důl and the Prachovské Rocks. In comparison to the answered questions about landforms, it is obvious that some districts are described only in general terms, due to the fact that the respondents did not want to name e.g. all rock formations in the Bohemian Paradise. Moreover, the respondents expressed themselves more generally about places that could be classified as paths: they mentioned cross country skiing trails in the Jizera Mountains, cycling trails in the Jizera 
Mountains and the Bohemian Paradise, and the hiking trails in the Jizera Mountains, the Lusatian Mountains and the Bohemian Paradise. Although there are significant trails, such as the Jizera Trail and the Golden Path of the Bohemian Paradise, these were not mentioned.

Among the cons of staying in the selected tourist areas of the Liberec Region, the dominant general statements include the following ones: too many tourists, bad behaviour of other tourists, poor accessibility by public transport, high prices, a lack of parking places, a lack of restaurants, etc. There is only one site, the chemical factory in Lovosice, which is perceived as a negative factor in the Bohemian Central Uplands. It is a pleasant finding that no more locations are perceived in a negative way; moreover, Lovosice lies outside the Liberec Region.

Tab. 2: Attendance in the selected tourist areas of the Liberec Region in 2014

\begin{tabular}{|l|c|c|}
\hline Tourist area & $\begin{array}{c}\text { Number of guests } \\
\text { [persons / year] }\end{array}$ & $\begin{array}{c}\text { Number of overnight stays } \\
\text { [persons / year] }\end{array}$ \\
\hline Giant Mountains & 219,020 & 829,932 \\
\hline Jizera Mountains & 142,403 & 493,745 \\
\hline Lusatian Mountains & 35,055 & 98,466 \\
\hline Bohemian Central Uplands & 15,948 & 35,041 \\
\hline Kokořín Region & 78,966 & 266,662 \\
\hline Bohemian Paradise & 75,153 & 181,120 \\
\hline
\end{tabular}

Source: [6], data from the Czech Statistical Office

To test the hypothesis on how the creation of a cognitive image of a tourist region affects its perceived attractiveness, we needed data about the attendance in these regions. These data are shown in Tab. 2. The data include only those parts of the tourist regions which are located in the Liberec Region. By far the most frequently visited area is the one of the Giant Mountains, followed by the Jizera Mountains, the Kokorrín Region and the Bohemian Paradise. On the other hand, a very low attendance was revealed for the areas of the Bohemian Central Uplands and the Lusatian Mountains, the regions which suffer from poor tourist infrastructure and insufficient promotion.

\section{Discussion}

When comparing the positives and negatives of tourists' stay in the selected tourist areas of the Liberec Region, it can be noted that tourists enjoy everything that will help them relax and unwind: stillness, tranquillity, nature and countryside views. Furthermore, they want to get involved in a light physical activity which they like and for which they do not have time during the week: hiking, biking, cross-country skiing, etc. For their activities, the tourists require good infrastructure; yet, this creates a paradoxical situation: good infrastructure attracts crowds of tourists instead of the desired peace. As a result, the tourists sometimes experience stress in these localities caused by the feeling of the space being overcrowded, the bad behaviour of other tourists and high prices. However, this situation increases the chances of less attractive locations, which could attract some tourists from the currently crowded localities.

The Liberec Region has the advantage that (with the exception of Frýdlant and its surroundings) it is easily accessible. However, as Drápela noted [7, 8], good transport infrastructure represents only a necessary condition for development, not its driving force. Without a good tourist infrastructure, it cannot be expected that people will invest money into 
spending their free time in this area. On the other hand, in some areas tourists complained about their commercialization, as the local entrepreneurs were trying to make profit from the large numbers of coming tourists and by selling them almost anything with the only aim to increase their earnings. This condition interferes with a pleasant, calm environment and, last but not least, destroys the sense of place.

Especially the perception of place is the key to understanding the process when some of the sites became the Lynch elements (especially landmarks) and some did not. Although the tourist can have some negative experience that is beyond one's control (e.g. a lost wallet, a car crashed in an accident), the number of respondents ensures us that these events have only a marginal effect. This means that e.g., monuments of equal importance might, or might not be considered a landmark. However, this was not confirmed. It can be illustrated on the example of Trosky and Kost castles. Both of them are among the most important castles in the Czech Republic, but only Trosky became a landmark. These castles are not far from each other, are promoted with the same intensity in the same leaflets, sometimes even on the same web page. So what is the shortcoming of Kost? This article will not provide an answer to this question because this would require further research. But this example is to show the ways that should be considered when designing effective marketing strategies for tourist areas.

\section{Conclusion}

The results of the questionnaire and its subsequent analysis reveal several main conclusions:

- From the Lynch elements in the answers of the respondents there is a strong dominance of landmarks followed by districts, at least tourists mentioned the paths. While landmarks were in most cases specific places, districts and especially paths were often named by general terms. This implies that the benefit of landmarks is the possibility of a specific denomination of an attractive place (in comparison with the general statement that the area is attractive).

- The questionnaire survey focused on the perception of the region by tourists who visited it. The results give us feedback on its strengths and weaknesses. It is a more valid source for evaluating the attractiveness of individual locations than hard data on attendance, from which we cannot detect the visitors' satisfaction. The negative experiences were reflected in their non-willingness to visit the site again or recommend it to friends.

- The number of the mentioned landmarks does not correlate with the number of visitors in these areas. The landmarks represent only a potential of attractiveness, but it is necessary to transform it into the real attendance. This requires to build up a sufficiently extensive and high-quality tourist infrastructure.

- To improve the attractiveness of the region, it is necessary to analyze why some sites have not been designated as landmarks, even though they are expected to. In these cases it is necessary to detect why their potential is not fulfilled. In many cases, it may be just a bad local organization with a conflict of interests of different groups of tourists. Therefore, improving the organization can improve the attractiveness of the place. In the worst case, a specific area can be completely without landmarks, in which case it is questionable whether it even has a potential for tourism.

- Landmarks do not have equal power to attract tourists, some are of regional importance only, whilst to some other ones people come from far and wide to visit them. What is more, the major importance is played not only by objective factors, but also the purity, genuineness and sense of place. Many tourists criticize the commercialization of nice places, which spoils them and turns them into markets or funfairs. 
- Creation of a cognitive image of a visited tourist area is a complex process, based on the mental representation of a spatial expression of holiday experiences. Compared with the mental maps of home surroundings or other familiar areas, in this mental map there is a significantly lower number of objects in it, many uncertainties and much more landmarks as the main destinations of trips. The cognitive image is further complemented by a layer of positive and negative preferences, as used e.g. by Gould and White [9]. This complex image then affects the perceived attractiveness of the region, when the concentration of neutral and negative feelings to a certain area causes its non-attractiveness.

\section{Literature}

[1] LYNCH, K.: The image of the city. MIT Press, Massachusetts, 1960. ISBN 9780262120043.

[2] TUAN, Y.-F.: Space and place: Humanistic perspective. Progress in Geography. 1974, Vol. 6, pp. 211-252.

[3] TUAN, Y.-F.: Space and place: The perspective of experience. University of Minnesota Press, Minneapolis, 1977. ISBN 0816608083.

[4] SIWEK, T.: Percepce geografického prostoru. Česká geografická společnost, Praha, 2011. ISBN 978-80-904521-7-6.

[5] VÁVRA, J.: Jedinec a místo, jedinec v místě, jedinec prostřednictvím místa. Geografie. 2010, Vol. 115, Issue 4, pp. 461-478. ISSN 1212-0014.

[6] BROŽKOVÁ, T.: Percepce velkoplošných chráněných území a prírodních parků Libereckého kraje z hlediska cestovního ruchu. Technická univerzita v Liberci, 2015.

[7] DRÁPELA, E.: Geographical location of depopulation areas in the Czech Republic and its dependence on transport infrastructure. Part I: Definition, methodology and quantitative analysis. Transactions on Transport Sciences. 2011. Vol. 4, Issue 1, pp. 3140. DOI: $\underline{10.2478 / \mathrm{v} 10158-011-0005-9}$. Vol. 4, Issue 1 of the journal available from: http://tots.cdv.cz/file/tots-2011-1/, all volumes available from: http://tots.cdv.cz/journaldownload/

[8] DRÁPELA, E.: Geographical location of depopulation areas in the Czech Republic and its dependence on transport infrastructure. Part II: Case studies. Transactions on Transport Sciences. 2011. Vol. 4, Issue 4, pp. 193-198. DOI: 10.2478/v10158-0110017-5. Vol. 4, Issue 4 of the journal available from: http://tots.cdv.cz/file/tots-2011-4/, all volumes available from: http://tots.cdv.cz/journal-download/

[9] GOULD, P., WHITE, R.: Mental maps. Penguin Books, Harmondsworth, 1974. ISBN 0415084822. 


\section{ROLE VÝZNAMNÝCH BODŮ V PERCEPCI ATRAKTIVITY REGIONU}

Na území Libereckého kraje existuje řada míst, která jsou velmi atraktivní pro různé formy turismu. V dotazníkovém šetření jsme se ptali turistů, kteří $\mathrm{v}$ této oblasti trávili svou dovolenou, co se jim líbilo nejvíce a co nejméně, jak hodnotí vybavenost a služby v regionu, a co by doporučili svým přátelům. Během vyhodnocování šetření jsme si uvědomili, že jedním z nejdůležitějších faktorů ovlivňujících celkovou percepci turistické oblasti je proces vzniku vnímaného prostoru skrze jeho části, významné body (landmarks). Tento článek se proto snaží odpovědět na otázku, jakým způsobem vzniká na základě prázdninových zážitků vnímaný prostor, a to pomocí dvou geografických teorií: konceptu místa a metody mentálního mapování. Porozumění tomuto procesu může $\mathrm{v}$ budoucnu přinést efektivnější formy propagace turistických oblastí.

\section{DIE BEDEUTUNG DER GRENZSTEINE FÜR DIE WAHRNEHMUNG DER ATTRAKTIVITÄT DER REGION}

Das Gebiet der Region Liberec enthält eine Reihe von Orten, die sehr attraktiv für verschiedene Formen des Tourismus sind. In der Umfrage baten wir Touristen, die diese Region besucht haben, uns mitzuteilen, was ihnen am meisten und was am wenigsten gefallen hat, wie sie die Einrichtungen und Dienste bewerten und was sie ihren Freunden empfehlen würden zu besuchen. Bei der Auswertung der Umfrage erkannten wir, dass einer der wichtigsten Faktoren, die die allgemeine Wahrnehmung der touristischen Bereiche bestimmen, der Prozess der Schaffung von wahrgenommenem Raum durch seine Teile ist, und zwar die Grenzsteine. Dieser Artikel versucht daher die Frage, wie der wahrgenommene Raum von den Erfahrungen erstellt wird, mit Hilfe zweier geographischer Methoden zu beantworten: des Konzeptes des Ortes und der Art der mentalen Erfassung. Das Verständnis dieses Prozesses kann in der Zukunft eine wirksamere Form der Förderung eines touristischen Gebietes bringen.

\section{ROLA PUNKTÓW ORIENTACYJNYCH W POSTRZEGANIU ATRAKCYJNOŚCI REGIONU}

W regionie libereckim jest wiele miejsc, które są bardzo atrakcyjne dla uprawiania różnych form turystyki. W przeprowadzonych badaniach ankietowych zapytaliśmy turystów, którzy w tym regionie spędzali swój wypoczynek, co im się najbardziej a co najmniej podobało, jak oceniają infrastrukturę i usługi świadczone $\mathrm{w}$ regionie, i co poleciliby swoim znajomym. W ramach oceny przeprowadzonych badań doszliśmy do wniosku, że jednym z najważniejszych czynników wpływających na ogólną percepcję regionu turystycznego jest proces powstania postrzeganej przestrzeni poprzez jej części, punkty orientacyjne (landmarki). W niniejszym artykule, przy pomocy dwóch teorii geograficznych - koncepcji miejsca i metody mapy myśli - spróbowano znaleźć odpowiedź na pytanie, w jaki sposób na bazie wakacyjnych wrażeń kształtuje się postrzeganie przestrzeni. Zrozumienie tego procesu może skutkować w przyszłości bardziej skuteczną formą promocji obszarów turystycznych. 